\title{
House prices and credit risk: Evidence from the United States 2 r
}

\author{
Mohammad Tajik ${ }^{\mathrm{a}, \mathrm{b}, *}$, Saeideh Aliakbari ${ }^{\mathrm{a}, \mathrm{c}}$, Thaana Ghalia ${ }^{\mathrm{a}}$, Sepideh Kaffash ${ }^{\mathrm{d}}$ \\ a Brunel University, Department of Economics and Finance, Uxbridge UB8 3PH, United Kingdom \\ b Brunel University, Department of Mathematics, Uxbridge UB8 3PH, United Kingdom \\ c Queen Mary University of London, School of Economics and Finance, London E1 4NS, United Kingdom \\ ${ }^{\mathrm{d}}$ University of Massachusetts Boston, Department of Accounting and Finance, 100 Morrissey Blvd., Boston, MA 02125, United States
}

\section{A R T I C L E I N F O}

\section{Article history:}

Accepted 7 August 2015

Available online 24 August 2015

\section{Keywords:}

Credit risk

Nonperforming loans

Banks

House prices

Loan categories

Dynamic panel data

\begin{abstract}
A B S T R A C T
This paper investigates the determinants of nonperforming loans (NPL), with a special focus on house price fluctuations. Using a panel of U.S. banks, the analysis is carried out across different loan categories and different types of banks. It is found that house price fluctuations significantly affect the dynamics of NPL, while the magnitude of the impact varies across loan categories and bank types.
\end{abstract}

(C) 2015 Elsevier B.V. All rights reserved.

\section{Introduction}

The recent subprime mortgage crisis in the United States has demonstrated the key role that the housing market plays in destabilizing the financial system. From the late 1990s, there was a sharp increase in the subprime mortgages fuelled by low interest rates and lax lending standards. However, while the quality of banks' loan portfolios was deteriorating by the constant growth of the subprime mortgages, the default rates remained artificially low due to the rapid house price appreciation. The booming house prices and low default rates encouraged banks to invest heavily in the real estate market, which eventually led to the creation of a speculative real estate bubble.

The collapse of the real estate bubble exerted enormous pressure on the banks that were highly exposed to the real estate market. In particular, many banking institutions suffered from severe liquidity shortages due to a sharp increase in their nonperforming

\footnotetext{
t5 We received helpful comments from Ana-Maria Fuertes, Alessandra Canepa, Mauro Costantini, Martin Ellison, Frank Skinner, Guglielmo Maria Caporale, Panagiotis Konstantinou, and the participants at the 9th BMRC-QASS Conference on Macro and Financial Economics in Brunel University. We are also grateful to two anonymous reviewers for their numerous valuable comments that have improved the paper.

* Corresponding author.

E-mail addresses: Mohammad.Tajik@brunel.ac.uk (M. Tajik), S.Aliakbari@qmul.ac.uk (S. Aliakbari),Thaana.Ghalia@brunel.ac.uk (T. Ghalia), Sepideh.Kaffash@umb.edu (S. Kaffash).
}

real estate loans. In fact, falling house prices undermined the value of real estate collaterals, which motivated many subprime mortgage borrowers to default on their loan repayments. Higher default rates, in turn, led to credit contraction and tightening of the lending standards in banks. As a consequence, the housing demand substantially dropped, while the housing supply was increasing due to the rising number of real estate foreclosures. The imbalances between supply and demand further reduced house prices and exacerbated deteriorating credit market conditions, which severely affected the real economy and led to high default rates across all loan categories.

Fig. 1 demonstrates the relationship between U.S. house prices, bank lending, and nonperforming loans (NPL). It appears that there is a close relationship between house prices, aggregate loan level, and aggregate NPL in the U.S. banking system. In other words, rising house prices are associated with increased lending and low default rates, while NPL increase substantially when house prices and real estate lending drop. In addition, Fig. 1 shows that NPL dynamics vary significantly across loan categories and bank types. More specifically, it appears that the impact of house price fluctuations is much higher on real estate loans, compared to other loan categories. It also emerges that, compared to savings institutions (SI), commercial banks (CB) suffer from higher loan losses in response to deteriorating market conditions.

Against this background, it is clear that understanding how house prices affect the quality of loan portfolios is of crucial importance to 


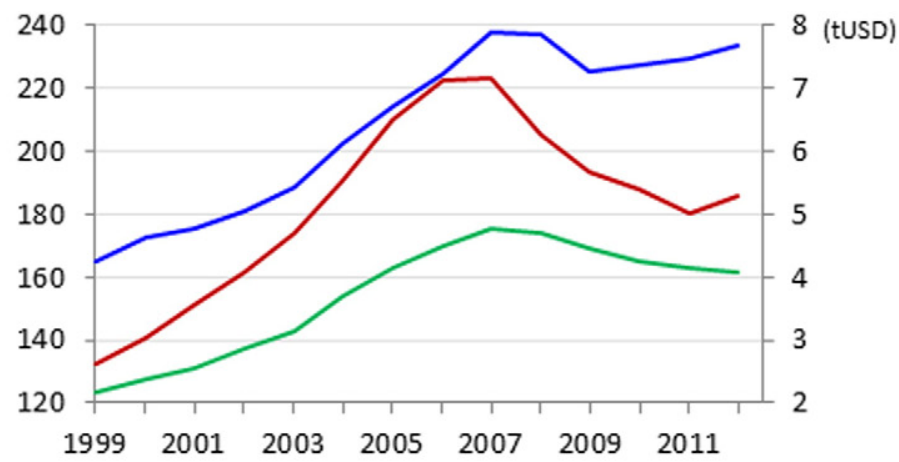

— House Price Index —Total Loans (tUSD) — Real Estate Loans (tUSD)

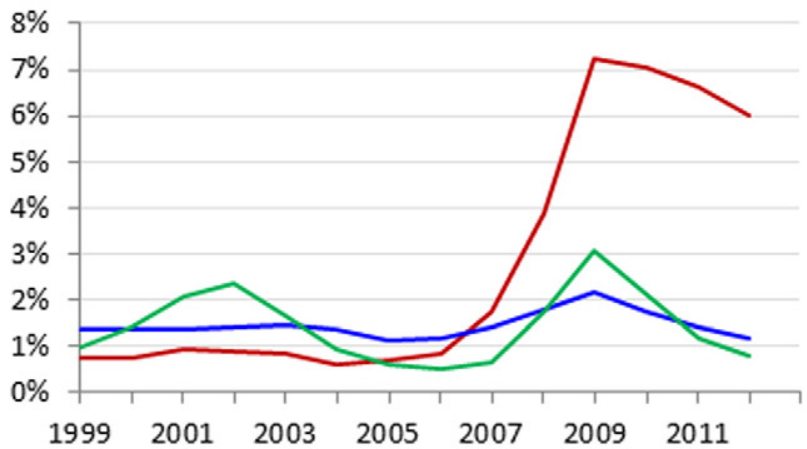

- Real Estate NPL $\quad$ Consumer NPL $\quad$ Commercial \& Industrial NPL

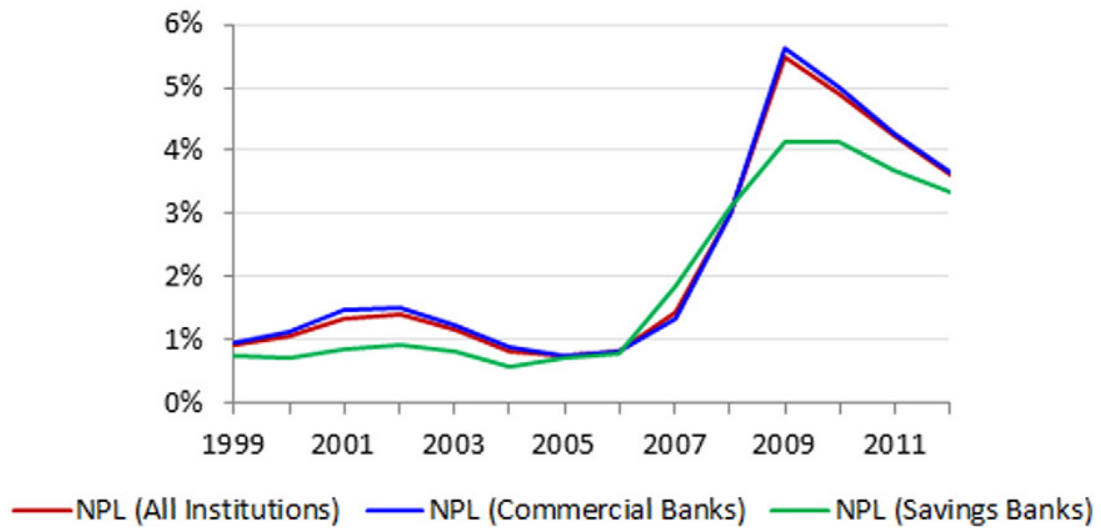

Fig. 1. House Price Index, aggregate lending behavior, and NPL dynamics across loan categories and bank types. Sources: FHFA and FDIC.

financial institutions and regulators interested in maintaining financial stability. Accordingly, this study uses dynamic panel data models to empirically investigate the impact of house price fluctuations on the evolution of NPL across U.S. banks. The analysis is further extended by examining if this relationship varies across different loan categories and different types of banks.

This paper complements the existing literature in several ways. First, we specifically examine the impact of house price fluctuations on the quality of loan portfolios at bank-level. Available empirical works focus primarily on the role of house prices in destabilizing the banking system as a whole (see, e.g., Reinhart and Rogoff (2008); Barrell et al. (2010)), while the impact of house prices on the quality of loan portfolios in individual banks is less investigated. Closely related to this particular aspect of our analysis, Pan and Wang (2013) study the threshold effects of income growth on the relationship between house prices and NPL. However, Pan and Wang (2013) only consider the asymmetric impact of house prices on NPL, whereas other credit risk determinants may also have asymmetric effects on default rates. In this empirical study, we account for potential asymmetric effects of all credit risk determinants on default rates by investigating NPL dynamics during different time periods.

Second, to the best of our knowledge, this is the first study that investigates how different loan categories are affected by house price movements. Using aggregate NPL to examine the relationship between house prices and the quality of loan portfolios may be challenged as the composition of loan portfolios varies widely across banking institutions (Louzis et al., 2012). In addition, it is evident in Fig. 1 that NPL dynamics vary substantially across different loan categories. Therefore, it is essential to investigate the sensitivity of different loan categories to house price fluctuations in order to develop an insight for financial regulators to provide better regulatory practices for individual banks with different loan portfolio compositions. 


\section{دريافت فورى ـ ـ متن كامل مقاله}

\section{ISIArticles}

مرجع مقالات تخصصى ايران

ل امكان دانلود نسخه تمام متن مقالات انكليسى ل امكان دانلود نسخه ترجمه شده مقالات ل يذيرش سفارش ترجمه تخصصى $\checkmark$ ل امكان جستجو در آرشيو جامعى از صدها موضوع و هزاران مقاله ل امكان دانلود رايكان r صفحه اول هر مقاله

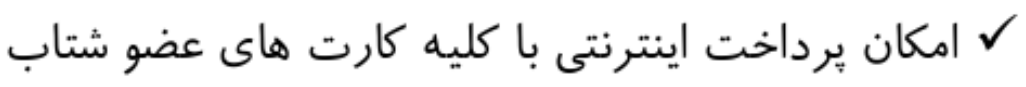
ل دانلود فورى مقاله پِ از برداخت آنلاين

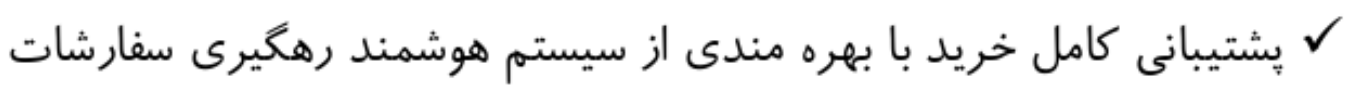

